\title{
Curbing Oil and Gas Companies Of Environmental Human Rights Violations through Community Participation/Sustainable Development in Niger Delta
}

\author{
Oghiagbephan, A. D. (Mispon, Masse, Mcasson) \\ Lecturer in the Dept. Of Educational Psychology, College Of Education, P.M.B. 1251, Warri-Delta State of \\ Nigeria
}

\begin{abstract}
The Niger-Delta is Africa's largest and the third largest mangroves forest in the world. It covers an area of about 70,000 sq.km and a population of about 31,217,889million. In designing a development programme, there must be a conscious effort to rely on the communities who are the target beneficiaries of such programme. Every society needs security without which lives and property cannot be secured. In the absence of security, the area will slide into a state of anarchy, chaos and the principle of survival of the fittest will hold sway. This is why government of all levels have to provide her citizenry with the services of law enforcement agencies for the general security with each having its own area of specialization. Man relies heavily on the environment, for shelter, food, clothing, health services, electricity and solar energy, transportation and economic activities. Environmental degradation therefore constitutes a violation of man's right to enjoy these benefits from the environment. Be that as it may, the paper highlights the concept of community participation, objectives of community participation, concept of sustainable Development, objectives of sustainable Development, sustainable Development for curbing Environmental Human Rights violation, violation of Environmental Human Rights by oil and gas companies and threat to Environmental and social justice. The paper also discusses the environmental Human Rights that are often abused in the said areas and finally, makes some recommendations necessary for sustainable development of the Niger-Delta.
\end{abstract}

\section{Introduction}

The Niger-Delta is Africa's largest mangrove forest area in the world. It covers an area of about 70,000 sq.kms (that is about $7.5 \%$ of Nigeria landmass) and has a population of about $31,217,889$ million (Vanguard, 2007, Wednesday, January, 10). The Niger-Delta region consist of nine (9) states: Abia, AkwaIbom, Bayelsa, Cross-River, Delta, Edo, Imo, Ondo and Rivers; and the adjoining shallow and deep off shore produce over 2 million barrels per day ( $\mathrm{mbd}$ ) of crude oil which accounts for about $95 \%$ of Nigeria's earning and about $85 \%$ of the revenue of the federation (Ojameruaye, 1996:6). The region has about 40 ethnic groups and about 1600 communities. The major economic activities in the area include agriculture, trading and oil related industries. Unemployment is a serious problem especially amongst the youth in this region. A significant feature of the Niger-Delta is its general state of underdevelopment (Ojameruay, 1999:6 Oghiagbephan, 2009:2627).

There is a widespread feeling of marginalization, neglect, oppression and deprivation amongst the people of the area. There is also a long history of intra and inter ethnic conflicts and deep mistrust which has made it difficult for the different groups in the region to form a united front to advocate for development and concession. Furthermore, traditional social structure, for example, the roles of elders and women, are being challenged and there is growing wave of youth agitation and militancy. Poor environmental practices such as sabotage - induced oil spillage, pipeline vandalisation which are inimical to sustainable development are also rampant in the region due to general poverty. The continued growth in human population and the rapid pace of industrial and economic development is placing increasingly heavy demand in the Niger-Delta's infinite natural resources. Conflicts, disasters and environmental emergencies are putting further pressure on the limited natural resources base. The over-exploitation of the earth's natural resources is so severe that it threatens the balance of many ecosystems around the Niger-Delta region.

Security measures the absence of fear, anxiety, tension, threat to life or apprehension of being in danger of losing life liberty, property and the core values. A nation is secure to the extent that it is not in a position to lose core values, life, property and liberty, and if it wishes, to deter, life, property and liberty and if it wishes, to deter aggression or win war when unavoidable. It is therefore to be noted that security provides the atmosphere for good or stable social and political order. The place of security in society is underscored by the fact that human life and every other sector of the system hingers on the function of security. This is why no nation in the world takes matters of security for granted and puts security on the top list when rating national interest. For 
instance life must be secure before man thinks about his food, clothing, shelter, and proceed to culture, politics and ideology. In other words security is the primary interest of a nation, as there is nothing absolute that gives meaning and essence to life except security.

According to Imobighe (1990) noted that security is sometimes mistakenly equated to only the barrel of the gun. He noted that there is security in bread, there is also security in social harmony, security in good health and security in political order. Security in a wholistic sense, measures all politics, laws and institutional set up aimed at giving the citizens as assured psychological feeling of internal and external vigilance and freedom from fear of losing core value. He further acknowledge that internal security is meaningful only when it creates the conducive atmosphere for the generality of the people to pursue their legitimate interest and realize their basic needs.

The success of any sustainable development initiative depends on the willing participation of all sectors of the society which continues to encourage decision makers in government, industry and business to develop and adopt environmentally sound policies, strategies, practices and technologies. This involves raising awareness, building international consensus, developing codes of practice and economic instruments, strengthening capacity exchanging information and initiating demonstration projects. This aims to promote investment in sustainable businesses and clearer production in developing the Niger-Delta region.

In designing development programmes, there must be a conscious effort to rely on the community who are the target beneficiaries of such programmes knowledge of local culture, political, power structure and other local peculiarities must be considered in the quest for community participation in the development process (Oghiagbephan, 2009:27).

\section{Concept of Community, Participation and Sustainable Development}

Concept of Community: The term community refers to people inhabiting a certain locality, having some degree of political autonomy, a sense of fellowship, a uniform set of religious beliefs, ethnic homogeneity, and often a particular dominant occupational function. It can also be referred to as a group of people located at a given geographical area with common goals and aspirations (Oghiagbephan, 2002:27).

Participation refers to the mobilization of people to undertake social and economic development projects. Here, the conception and design of projects are done by higher authorities; communities are then mobilized for their implementation. Participation by the people is made up in this instance of labour and material resources, usually offered free or paid for by the government or project authorities. Another interpretation of participation equates with decentralization in government machinery and policy making process. It is also viewed as a process of empowerment of the deprived and the excluded. This view is predicted on the recognition of socio-economic inequalities. It is interpreted specifically as enhancing the power of the power of the deprived masses (Oghiagbephan, 2002 and Prosor, 2002).

\section{Community Participation}

Community participation is a concept which describes the involvement of the people at the local level in making choices for the development of their communities. It is based on self-confidence and the possession of the capabilities to plan and take actions to solve their own problems with little or no assistance from the outside.

However, the basic assumptions underlying community participation in development programmes include:

- $\quad$ People from both rural and urban are willing to cooperate and work with one another;

- Such cooperation will not be prevented or exploited by local elites;

- $\quad$ People organize best around problems or needs they consider most important;

- There will be voluntary contribution of labour, time, materials and money towards implementing community programmes and projects by the peoples;

- Local control over the amount, quality and especially the distribution of benefits from development activities is directly related to those benefits becoming self-sustaining and

- Programmes in which local people have played a significant part both in the planning and implementation phases will be more effective and successful than centrally devised schemes.

\section{The Concept of Sustainable Development}

Sustainable Development could be regarded as a process of change in which the exploitation of resources, the direction of investments, the orientation of technological development and institutional change are all in harmony and enhance both current and future potential to meet human needs and aspirations. Consequently, satisfying human aspirations and needs is the major objective of development while sustainable dev elopement is development which meets the needs of the present generation without compromising the ability of future generations to meet their own needs. 
Sustainable human development stresses the importance of participation as a means of sustain the development process and to ensure a more equitable distribution of beneficiaries created by development initiatives. Its main focus is the utilization of national resources (physical and human) to:

a. meet the Niger-Delta needs;

b. achieve sustainable livelihood systems in a given community

c. eliminate poverty

d. maintain the physical and human environment for the present as well as succeeding generations of members of the community and above all.

e. achieve global inclusion by ensuring the mobilization of the participation of all members of the community in the development process as well as equitable distribution of benefits produced.

The shift is however emphasizing the programme approach which encourage a national participatory process in development management involving all major stakeholders/beneficiaries including development partners and donors (UNDP, 1996:50-51, Oghiagbephan, 2002:27).

\section{Objectives of Sustainable Development}

The objectives of sustainable development are numerous amongst these include:

1. To ensure that the natural or environmental resources base is not allowed to deteriorate.

2. To combat environmental abuse by observing environmental human rights and ethics in industrial activities.

3. To educate people and nations on the need for Environmental Impact Assessment (EIA) before carryout a development project.

4. To identify the cause of environment degradation, biodiversity loss and other environmental problems and to combat them.

5. To create a sustainable improvement in the quality of life for all people as a principal goal of development.

6. To meet the basic needs of people of the present generation in order to sustain the needs for future generations.

7. To increase economic growth

8. To ensure clean environment for all

9. To show that there are principles of environmental ethnic governing the utilization of environmental resources for development purposes.

10. To give everyone the chance to participate in public life

11. To uplift the living standards of people by meeting their basic needs

12. To ensure observation of certain basic environmental human rights.

13. To better people health and enhance their educational opportunities (Jhingan and Sharma, 2009).

\section{Sustainable Development for Curbing Environmental Human Right Violation}

There are several definitions of sustainable development but the one given by the Brundtland report is the most popular. According to the report, sustainable development seeks to meet the needs and aspirations of the present generation without compromising the ability to meet those of the future.

Individuals and nations use all possible means and power to control the envonrment as a means of fulfilling their immediate development needs with the adverse consequences of violations of environmental human rights sustainable development is a bold measure to socialize all nations and their citizens into a behaviour towards the environment that will guarantee environmental human right for both the present and future generations. World summit on sustainable development has urged the need for peace, security, stability and respect for human rights and fundamental freedom including the right to development, as well as respect for cultural diversity. These are essential for achieving sustainable development and ensuring that sustainable development benefits all. The United Nations (UN) recognizes that sustainable development links the right to development and the right to a secure, healthy and ecologically sound development (UNDP, 1996).

\section{Violation of Environmental Human Rights by Oil and Gas Companies}

It is difficult to secure a stable polity if the environmental human rights are restlessly abused or violated, like we have in the Niger-Delta region of Nigeria. Insecurity arises as an effect of poverty, violation of human rights and marginalization of minority groups in a region or community. When demand or requests for redressing are ignored, they often escalate to threats, agitations and social campaigns.

Internal security challenges are also medicated by environmental factors, environmental degradation constitutes a violation of environmental human rights. Human rights are violated when environmental hazards are created by the abilities of the oil and gas companies in Nigeria and other industrial activities in Nigeria.

The Niger-Delta environment in Nigeria has been damaged due to the activities of oil and gas companies. Not only has their physical environment being damaged, but their source of livelihood has been destroyed due to the contamination of the fishing areas by oil spills, gas flaring and chemical waste dumped into 
the environment by these companies. The major oil exploration companies have consistently refused to adopt environmental-friendly technologies and practices. Consequently host communities have been denied of their right to fishing, farming and healthy environment for living. This is the source of host communities and oil and gas hostilities in Niger-Delta. It may furthermore be noted that so far about 400 oil wells have been drilled in the Niger-Delta and offshore areas since the commencement of oil exploration in Nigeria in 1957. These 400 sites remain polluted areas as drilling wastes, drilling cutting, oil sledges and other different hazardous chemicals have been dumped without the needed site remediation. Oil spills and leaks have turned the oil-rich Niger Delta in to devastated and barren wastelands.

The Niger-Delta region is today known to be crisis-crossed by buried or exposed pipelines that connect the producing well with oil flow stations, refineries, crude oils and products loading terminals and depots. The Niger-Delta region today suffers from coastal and land erosion, biodiversity loss, degraded and infertile agricultural farmland and loss of fishing grounds (Akindele and Bassey, 2000 and Ozekhome, 2001).

\section{Threat to Environmental and Social Justice}

In most of the oil producing Niger-Delta area, the people are facing the problems of severe dearth of infrastructural facilities in health, educational and social sections like motorable road network, potable water and electricity. There is widespread unemployment among the youths who have become restive as a result of these heinous environmental crimes against the people and their environment. Protest and agitation of the people for compensation and better environmental management have been rebuffed and their leaders jailed or killed. These environmental crimes against the people have given rise to militancy, kidnapping of expatriate oil workers, pipeline vandalisations, shut down of oil facilities. Compensation for some of these crimes by oil and gas companies have pitched ethnic group against one another, over conflicting claims of ownership are usually in the nature of (i) between oil-producing communities (ii) between oil and gas companies and oil and gasbearing communities and (iii) between the government and oil/gas-bearing communities (Olagoke, 1996 and Jhinga, 2006).

\section{Some Environmental Human Rights often Abused in Nigeria}

Jhingan, Chander and Sharma (2009), listed some of the environmental human rights being abused or violated in Nigeria and elsewhere which also applies to the Niger-Delta region. These include:

1. All persons have the right to freedom from pollution, environmental degradation and activities that adversely affect the environment, threaten life, health, livelihood, well-being or sustainable development within, across or outside national boundaries.

2. All persons have the right to associate freely and peacefully with others for purposes of protecting the environment.

3. All persons have the right to protection and preservation of the air, soil, water, sea, flora and fauna, and areas necessary to maintain biological diversity and ecosystem.

4. All persons have the right to an environment adequate to meet equitably the needs of present generations and that does not impair the right of future generation to meet equitably their needs.

5. All persons have the right to timely assistance in the event of natural or technological or other humancaused catastrophes.

6. All persons have the right to safe and healthy food and water adequate for their well-being.

7. All persons shall be free from any form of discrimination in regard to actions and decisions that affect the environment.

8. Indigenous people have the right to control their lands, territories and natural resources and to maintain their traditional way of life.

9. All persons have the right to the highest attainable standard of health free from environmental harm.

10. All persons have the right to a secure, healthy and ecologically sound environment. This right and other human right, including civil, cultural economic, political and social rights are universal, interdependent and indivisible.

11. All persons have the right to adequate housing, land tenure and living conditions in a secure, healthy and ecologically sound environment.

12. All persons have the right to a safe and healthy working environment. 


\section{Conclusion and Recommendations}

Although oil exploitation has helped to achieve impressive economic growth and development in Nigeria, little or no attention has been directed to soften the adverse impacts on the oil/gas-bearing communities. The lack of attention can be attributed to the international orientation of oil enterprise which is exclusively operated by multinational corporation from a capitalist point of view without regard to the welfare of the producing communities though the Federal Government of Nigeria and the oil and gas companies are partners in the oil business, yet there has been no significant policy for enhancing the welfare of the people. The people become restive and pose serious security challenges to the nation because of the combination of the following factors; destruction of farmland, destruction of biodiversity, contamination1 of water supply sources; lose of job by the indigenous, acid rain and impairment of the Aesthetic quality of the oil and gas production zone (Akpofure, Efere and Ayawe, 2000).

Conclusively, the paper looked at the concept of community, community participation, concept of sustainable development, objectives of sustainable development and sustainable development for curbing environmental human rights violation. It went further to discuss the violation of environmental human right by oil and gas companies, threat to environmental and social justice, some environmental human rights that are often abused in Nigeria, and finally, some recommendations necessary for sustainable development in the Niger-Delta region were proffered.

\section{Recommendations}

It must be noted that economic activities and economic development have a1 direct bearing on the natural and environmental resources. Oil producing activities certainly add stress to the environment and affect its assimilative capacity, the following recommendations are made:

1. A formal community impact agreement between oil companies and oil bearing communities.

2. There should be a permanent relief programme by the Federal Government and oil companies to ensure that environmental disasters occasioned by oil production are contained as quickly and fast as possible.

3. Inclusion of environmental degradation and emergency issues in the process of national development.

4. The oil and gas companies need to be made to fulfill the social responsibilities to the oil-bearing communities by restoring the ecosystem.

5. There should be strong legislation against pollution of the environment.

6. Regular maintenance of oil pipelines, there should also be regular monitoring of these facilities to detect leakage and prevent vandalisation (Ikem, 1990:191).

Nevertheless, the Niger-Delta region is critical to the present and future development of the Nigeria. Therefore, there is need to ensure sustainable development of the region. To ensure sustainable development of the region a multi-disciplinary and multi-stakeholders approach is necessary. No single government or agency or company can tackle the seemingly serious problems of the region.

1. There must be a common vision and clearly defined roles and responsibilities for all stakeholders.

2. All key companies operating in the region should have and implement community development and environmental plans for their host communities to Sustainable Development (SD).

3. Host communities should be involved in the design, planning, implementation, monitoring and evaluation of such plans.

4. The institution (Niger Delta Development Commission - NDDC) which was formed to cater for this region should be adequately funded and managed in a transparent, accountable and competitive manner.

5. The Niger Delta Environmental survey should be transformed into the research, planning and statistics unit of the NDDC.

6. Stakeholders coordinating committees should be set up in each of the 9 stakes - Abia, Akwa-Ibom, Bayelsa, Cross-River, Delta, Edo, Imo, Ondo and Rivers that make up the Niger-Delta region to avoid duplication of efforts and resolve community/private sector and inter-intra-communal conflicts.

7. All ailing and mori-bund industries (for example Delta Steel Complex, the Warri, Koko, Sapele, Calabar ports) should be rehabilitated and new ones should be established including industrial estates in key cities within the Niger Delta (SPDC Annual Report 1998, Oghiagbephan, 2002 and 2005:28-30). 


\section{References}

[1]. Akindele, R.A. and Bassey, E.A. (ed) (2000). Selected Readings on Nigeria Foreign Policy and International Relations: NIIA Enlightenment: Course Series, Vol. 1, pp. 80-82.

[2]. Akpofure, E.A., Efere, M.L. and Ayawei, P. (2000). The Adverse Effects of Crude Oil Spills in the Niger-Delta, Urhobo: Historical Society.

[3]. Bolade, O. (2007). Provisional Population Total 2006, Vanguard Wednesday, January 10, Vol. 23, (60242), p. 1.

[4]. Ikein, A.A. (1990). The Impact of Oil on a Developing Nation, Praeger.

[5]. Imobighe, T.A. (1990). Doctrines for and Threats to Internal Security: In Ekoko and Vogt (1990) (ed.) Nigeria Defence Policy: Issues and Problems, pp. 223-236.

[6]. Jhingan, M.L. (2006). Economics of Development and Planning, Deltu: Vrinda Publications Ltd.

[7]. Jhingan, M.L., Chander, K. and Sharma, P. (2009). Environmental Economics, Theory, Management and Policy, Delhi: Vrinda Publications Ltd.

[8]. Oghiagbephan, A.D. (2002). "Notables Roles/Contributions of the Oil Industries to their Host Communities". In HSE Competence Development Programme: Level 3, Warri: NISP, p. 57-59.

[9]. Oghiagbephan, A.D. (2005). "Community Affairs in Niger-Delta". In Contractor Employee HSE Training Manual, Level 3, Nigerian Institute of Safety Professionals (NISP), Warri: NISP, p. 80-85.

[10]. Oghiagbephan, A.D., Ikekhua, A.I.O. and Oyearone, P.E. (2009). "Community Development for Sustainable Development/Participation of the Niger-Delta": EDUCERE Journal of Educational Research. Ijagun, Ijebu-Ode: Published by Tai Solarin University of Education, Vol. 5, May/June, p. 26-30.

[11]. Ojameruaye, E. (1999). "SPDC's Community Development Programme", The Community, Warri: SPDC Quarterly Publication, Vol. 2(3), p. 6-8.

[12]. Olagoke, W. (1996). Niger-Delta Environmental Survey: Which Way Forward: Ultimate Water Technology and Environment.

[13]. Ozekhome, M. (2001). Legislation for Growth in the Niger Delta, Midweek: Pioneer.

[14]. Pearce, B. and Markandya, O.D. (1990). Sustainable Development, UNDP, Accra: Module 1, Unit 1, p. 51-52.

[15]. Prosor, L. (2002). Capacity Building for Sustainable Development: The Role of UNDP, Johannesburg, p. 11-14.

[16]. SPDC Annual Report (1998). People and the Environment, Lagos: SPDC Annual Publications, p. 6-11.

[17]. UNDP (1996). Sustainable Human Development: A Guide to Practitioners, Module 1, Unit 1, Session 2, p. 50-56. 